Original Article

\title{
A VALIDATED GRADIENT STABILITY-INDICATING LC METHOD FOR THE ANALYSIS OF VALSARTAN IN PHARMACEUTICAL DOSAGE FORM
}

\author{
TRIPTI SHARMA*1a, SUDAM CHANDRA SI ${ }^{\mathrm{a}}$ \\ aDepartment of Pharmaceutical Chemistry, School of Pharmaceutical Sciences, Siksha '0' Anusandhan University, Bhubaneswar 751003, India \\ Email: triptisharma@soauniversity.ac.in
}

Received: 04 May 2016 Revised and Accepted: 22 Jul 2016

ABSTRACT

Objective: The objective of this research work was to develop a sensitive, precise, specific, linear and stability-indicating gradient HPLC method for the estimation of valsartan in bulk drug and in pharmaceutical preparations.

Methods: Chromatographic separation was achieved on C-18 stationary phase with a gradient mobile phase consisting of orthophosphoric acid buffer (the $\mathrm{pH}$ of the solution was adjusted to $4.2 \pm 0.05$ with triethylamine) and methanol. The eluent was monitored with PDA detector at $225 \mathrm{~nm}$ with a flow rate of $1.0 \mathrm{ml} / \mathrm{min}$, run time of $65 \mathrm{~min}$.

Results: The method was linear over the range of $20-120 \mu \mathrm{g} / \mathrm{ml}$. The correlation coefficient was found to be $0.9994 \pm 0.02$. In order to check the selectivity of the method for pharmaceutical preparations, forced degradation studies were carried out. Valsartan was found to be stable at light and oxidation experiments. The performance of the method was validated according to the present ICH guidelines for specificity, limit of detection, limit of quantification, linearity, accuracy, precision and robustness. .The LOQ was found to be $0.26 \mu \mathrm{g} / \mathrm{ml}$ and the $\mathrm{LOD}$ was found to be $0.79 \mu \mathrm{g} / \mathrm{ml}$. Valsartan showed good correlation coefficient in the concentration range of $20-120 \mu \mathrm{g} / \mathrm{ml}$. The developed method was compared statistically by applying two-way anova and student's t-test to correlate with an isocratic method and was applied to bulk drug and tablet dosage form. There was no significant difference between the two methods.

Conclusion: The proposed method was found to be accurate, precise, sensitive and robust. Hence, it can be used successfully for the routine analysis of valsartan in pharmaceutical formulation and for analysis of stability samples obtained during accelerated stability study.

Keywords: RP-HPLC, Valsartan, Degradation products, Pharmaceutical dosage forms, Two-way ANOVA and student's $t$-test

(C) 2016 The Authors. Published by Innovare Academic Sciences Pvt Ltd. This is an open access article under the CC BY license (http://creativecommons. org/licenses/by/4. 0/) DOI: http://dx.doi.org/10.22159/ijpps.2016v8i9.12581

\section{INTRODUCTION}

Valsartan (VAL) is chemically N-(1-0xopentyl)-N-[2'-(1H-tetrazol-5yl) [1,1'-biphenyl]-4-yl] methyl]-L-valine.[1] It is a new potent, highly selective and orally active antihypertensive drug belonging to the family of Angiotensin II type I receptor antagonist. Angiotensin II receptor type I antagonists have widely used in the treatment of hypertension, heart failure, myocardial infarction and diabetic nephropathy.[2] Literature survey revealed that HPLC, LC-MS, protein precipitation, capillary electrophoresis and simultaneous UVspectrophotometric methods [3-15] are reported for estimation of VAL alone or on combination with other agents. As the published literature and knowledge of the molecule suggest, reversed phase liquid chromatography (RP-HPLC) is suitable for analysis of VAL. various methods are available for estimation of VAL in isocratic mode, but as the main aim was to resolve the compound from degraded products and impurities if any, the gradient method was chosen.

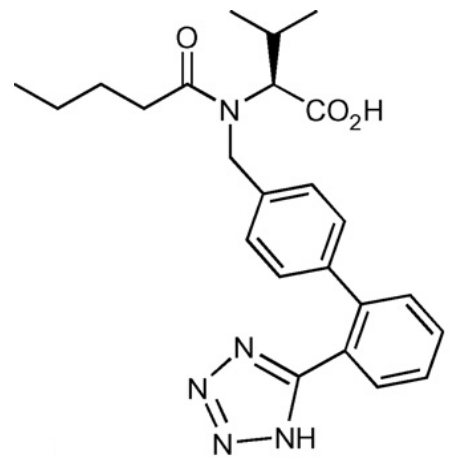

Fig. 1: Chemical structure of Valsartan

\section{MATERIALS AND METHODS}

\section{Chemicals and reagents}

A reference standard sample of VAL was obtained as a gift from Macleod's Pharmaceuticals Ltd and commercial dosage form containing the studied drug were purchased from local market. HPLC grade methanol, orthophosphoric acid, triethylamine, and water were HPLC grade purchased from E. Merck, Mumbai, India. All the other chemicals and reagents used were of analytical grade and purchased from SD Fine Chemicals, Mumbai, India.

\section{Instrumentation and chromatographic system}

The chromatographic system consisted of a JASCO (Japan) chromatograph equipped with an LC-Net II/ADC, an MU-2010 plus PDA detector, a PU-2089 plus quaternary pump, an online degasser and a rheodyne model 7725 injector valve with $20 \mu$ sample loop. The chromatograph is coupled with "Chrompass" software (version 1.7.403.1).

The chromatographic separations were performed at ambient temperature using Symmetry C18 column $(4.6 \mathrm{~mm} \times 150 \mathrm{~mm}$, particle size $5.0 \mu \mathrm{m}$ ). Separation was achieved using a gradient method. Mobile phase A comprised of orthophosphoric acid buffer (the $\mathrm{pH}$ of the solution was adjusted to $4.2 \pm 0.05$ with triethylamine). Mobile phase B was methanol. orthophoshoric acid buffer ( $\mathrm{pH} 4.2)$ was prepared by adding $5.5 \mathrm{ml}$ of orthophosphoric acid in $1000 \mathrm{ml}$ of HPLC grade water, adjusting the $\mathrm{pH}$ to $4.2 \pm 0.05$ with triethylamine, diluting to $1000 \mathrm{ml}$ with HPLC-grade water, and filtering through $0.45 \mu \mathrm{m}$ membrane filter. For the preparation of diluent, a mixture of buffer $\mathrm{pH} 4.2$ and methanol (50:50v/v) filtered and degassed for $30 \mathrm{~min}$ prior to use. The eluent was monitored with PDA detector at $225 \mathrm{~nm}$ with a flow rate of $1.0 \mathrm{ml} / \mathrm{min}$, run time of $65 \mathrm{~min}$; sample size of $20 \mu \mathrm{l}$ was carried out at room temperature all over the study. 
Table 1: Gradient composition for analysis of VAL

\begin{tabular}{llll}
\hline Time (min) & Mobile phase A (\% v/v) & Mobile phase B (\% v/v) & Comment \\
\hline $0 \rightarrow 40$ & 55 & 45 & Isocratic \\
$40 \rightarrow 55$ & $55 \rightarrow 20$ & $45 \rightarrow 80$ & Linear gradient \\
$55 \rightarrow 57$ & 20 & 80 & Isocratic \\
$57 \rightarrow 58$ & $20 \rightarrow 55$ & $80 \rightarrow 45$ & Linear gradient \\
$58 \rightarrow 65$ & 55 & 45 & Re-equilibration \\
\hline
\end{tabular}

\section{Preparation of stock solution}

Stock solutions were prepared by accurately weighing $10 \mathrm{mg}$ of VAL and transferring to $10 \mathrm{ml}$ volumetric flasks containing $6 \mathrm{ml}$ of methanol. The flasks were sonicated for $10 \mathrm{~min}$ to dissolve the solids. Volumes were made up to the mark with diluents, which gave $1000 \mu \mathrm{g} / \mathrm{ml}$ the drugs. Aliquots from the stock solutions were appropriately diluted with diluents to obtain working standards of $100 \mu \mathrm{g} / \mathrm{ml}$ of $\mathrm{VAL}$

\section{Calibration standards and quality control sample}

Different calibration standards ranging from 20, 40, 60, 80, 100 and $120 \mu \mathrm{g} / \mathrm{ml}$ were prepared by appropriate dilution of standard solution $(1000 \mu \mathrm{g} / \mathrm{ml})$ with mobile phase. Three quality control samples at concentrations 60,80 and $100 \mu \mathrm{g} / \mathrm{ml}$ representing 50 , 100 and $150 \%$ respectively of assay concentration $(40 \mu \mathrm{g} / \mathrm{ml})$ were prepared from the standard solution. An aliquot of $20 \mu \mathrm{L}$ of the solution was injected into HPLC system.

\section{Preparation of assay solution}

To determine the VAL content of tablet formulations, twenty tablets were weighed, to determine the average weight of the tablets, and then crushed and mixed using a mortar and pestle. A portion of powder equivalent to $1000 \mu \mathrm{g} / \mathrm{ml}$ was accurately weighed into each of three $10 \mathrm{ml}$ volumetric flasks and $5 \mathrm{ml}$ methanol was added. Each solution was sonicated for $20 \mathrm{~min}$ to achieve complete dissolution of the VAL and the solutions were then diluted to volume with diluents, to yield concentrations of $1000 \mu \mathrm{g} / \mathrm{ml}$, and filtered through a $0.22 \mu \mathrm{m}$ nylon membrane filter. The solution obtained was analyzed by HPLC.

\section{Forced degradation study}

\section{Acidic degradation}

$50 \mathrm{mg}$ of VAL was accurately weighed and dissolved in $10 \mathrm{ml}$ of methanol, then $5 \mathrm{ml}$ of $0.1 \mathrm{~N} \mathrm{HCl}$ were added and kept at $80^{\circ} \mathrm{C}$ about $2 \mathrm{~h}$ in a water bath, the solution was allowed to attend ambient temperature then the solution was neutralized by $0.1 \mathrm{~N} \mathrm{NaOH}$ to $\mathrm{pH}$ 7 and the volume made up to $50 \mathrm{ml}$ with methanol.

\section{Alkali degradation}

$50 \mathrm{mg}$ of VAL was accurately weighed and dissolved in $10 \mathrm{ml}$ of methanol, then $5 \mathrm{ml}$ of $0.1 \mathrm{~N} \mathrm{NaOH}$ was added and kept at $80{ }^{\circ} \mathrm{C}$ about $2 \mathrm{~h}$ in a water bath. Then the solution was neutralized by $0.1 \mathrm{~N} \mathrm{HCl}$ to $\mathrm{pH} 7$ and the volume made up to $50 \mathrm{ml}$ with methanol.

\section{Oxidative degradation}

$50 \mathrm{mg}$ of VAL was accurately weighed and dissolved in $10 \mathrm{ml}$ of methanol, then $5 \mathrm{ml}$ of $10 \% \mathrm{H}_{2} \mathrm{O}_{2}$ solution were added and kept at 80 ${ }^{\circ} \mathrm{C}$ about $2 \mathrm{~h}$ in a water bath then volume was made up to $50 \mathrm{ml}$ with methanol.

\section{Thermal degradation}

$50 \mathrm{mg}$ of VAL was spread in a borosilicate glass Petri dish and placed in a hot air oven maintained at $80^{\circ} \mathrm{C}$ for $24 \mathrm{~h}$, and then the solution was prepared to achieve a final concentration of $80 \mu \mathrm{g} / \mathrm{ml}$ with methanol.

\section{Photodegradation}

$50 \mathrm{mg}$ of VAL was (covered with aluminum foil) and exposed in the UV chamber for $24 \mathrm{~h}$; then the solution was prepared to achieve a final concentration of $80 \mu \mathrm{g} / \mathrm{ml}$ with methanol.

\section{Method validation}

The method was validated according to International Conference on Harmonization [17] guidelines for validation of analytical procedures.

\section{RESULTS AND DISCUSSION}

\section{HPLC method development and optimization}

Some important parameters, like $\mathrm{pH}$ of the mobile phase, concentration of buffer solution, percentage and type of organic modifiers (acetonitrile and methanol), different columns (CN column, C8 and C18), flow rates ( 0.5 to $2.0 \mathrm{ml} / \mathrm{min}$ ) were attempted to resolve the good chromatographic separation of VAL. VAL and degraded products could not be separated without $\mathrm{pH}$ adjustment of the mobile phase. Various pH ranges ( 3 to 6) for mobile phase were tried, and the best resolution was obtained with $\mathrm{pH} 4.2$.

The method was optimized to provide a good separation of the components (acceptable theoretical plates and resolution between peaks) with a sufficient sensitivity and suitable peak symmetry (peak tailing factor<2). Symmetry C18 column $(4.6 \mathrm{~mm} \times 150 \mathrm{~mm}$, $5.0 \mu \mathrm{m}$ particles were preferred over the other columns. The mobile phase consisted of 55\% phosphate buffer and $45 \%$ methanol to $80 \%$ buffer and $20 \%$ methanol within $40 \mathrm{~min}$ with a $1 \mathrm{ml} / \mathrm{min}$ flow rate. Retention times for VAL under these conditions were 27.04 (fig. 2). The quantitative analysis of the drug and its degradation products were performed at $225 \mathrm{~nm}$.

Gonzalez et al. [5] developed a HPLC method coupled to fluorescence detection using gradient elution mode and was applied to plasma samples obtained from hypertensive patients under clinical studies after oral administration of a therapeutic dose of some of these angiotensin II receptor antagonists. The objective of this research work reported was to develop a simple, precise, accurate gradient stability-indicating LC method for analysis of VAL in bulk and its formulations in the presence of degradation products and impurities.

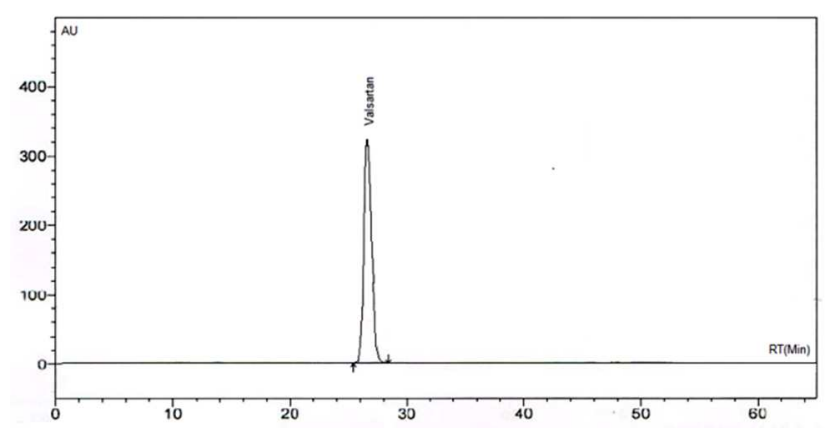

Fig. 2: HPLC chromatogram of valsartan (pure drug) in gradient mode

\section{Method validation}

\section{System suitability}

System suitability test is an integral part of method development and is used to ensure adequate performance of the chromatographic system. Retention time, a number of theoretical plates, asymmetrical factor, and peak area were evaluated for five replicate injections of 
the drug at a concentration of $80 \mu \mathrm{g} / \mathrm{ml}$. The results given in table 2 were within acceptable limits.

Table 2: System suitability of HPLC method for VAL

\begin{tabular}{ll}
\hline Parameters & (Mean* $\mathbf{0} \% \mathbf{R D})$ \\
\hline Retention time & $27.04 \pm 0.59$ \\
No. of theoretical plates & $9154.2 \pm 0.72$ \\
Asymmetrical factor & $1.05 \pm 0.47$ \\
Peak area & $7050360 \pm 0.68$ \\
\hline
\end{tabular}

*Mean of five determinations

\section{Linearity}

VAL showed good correlation coefficient in the concentration range of $20-120 \mu \mathrm{g} / \mathrm{ml}$ (fig. 3). Linearity was calculated by determining six standard working solutions containing VAL in triplicate (table 3). For the method, the linearity of calibration graph was validated by the high value of correlation of coefficient and the RSD for slope and intercept value was less than $2 \%$.

Table 3: Linear regression data for calibration curve of VAL

\begin{tabular}{ll}
\hline Parameters & VAL \\
\hline Linearity range $(\mu \mathrm{g} / \mathrm{ml})$ & $20-120$ \\
$\mathrm{r}^{*} \pm \mathrm{RSD} \%$ & $0.9994 \pm 0.02$ \\
Slope ${ }^{*} \mathrm{RSD} \%$ & $94265 \pm 0.26$ \\
Intercept* ${ }^{*} \mathrm{RSD} \%$. & $453560 \pm 1.60$ \\
\hline
\end{tabular}

*Mean of three determinations

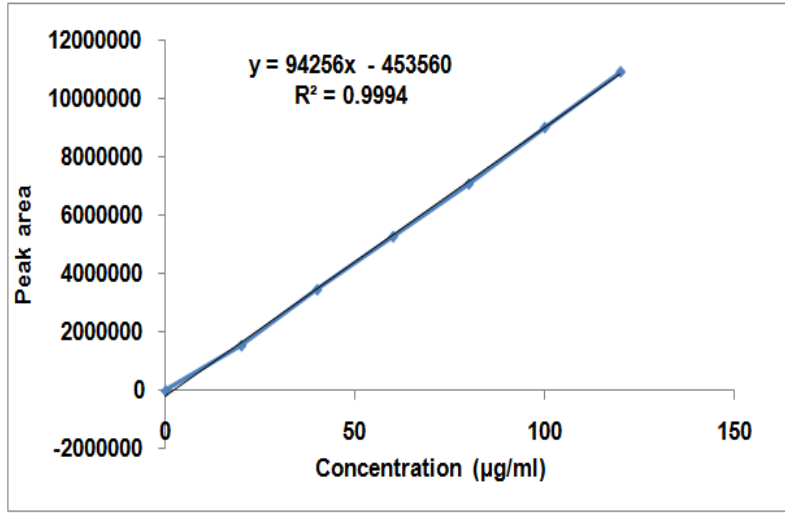

Fig. 3: Calibration curve of valsartan in gradient mode

\section{Accuracy}

The accuracy of the method was checked by recovery study using standard addition method known the amount of standard VAL was added into the pre-analyzed sample and subjected it to the proposed high performance liquid chromatographic method.

These studies were carried out at three levels i. e, (50, 100 and 150\%). The recovery studies were carried out and the \% recovery and standard deviation of the \% recovery were calculated and presented in table 4 .

Table 4: Recovery study by standard addition method for VAL

\begin{tabular}{|c|c|c|c|c|c|}
\hline Sample & Amount taken $(\mu \mathrm{g} / \mathrm{ml})$ & Amount \% & $\begin{array}{l}\text { Amount added } \\
(\mu \mathrm{g} / \mathrm{ml})\end{array}$ & Mean amount present $(\mu \mathrm{g} / \mathrm{ml})$ & $\begin{array}{l}\text { Recovery mean* } \\
(\%) \pm \text { SD }\end{array}$ \\
\hline \multirow{3}{*}{ Valzaar-80 } & 40 & 50 & 20 & 60 & $99.98 \pm 0.25$ \\
\hline & 40 & 100 & 40 & 80 & $99.90 \pm 0.35$ \\
\hline & 40 & 150 & 60 & 100 & $99.82 \pm 0.55$ \\
\hline \multirow{3}{*}{ Diavon-80 } & 40 & 50 & 20 & 60 & $100.21 \pm 0.47$ \\
\hline & 40 & 100 & 40 & 80 & $99.94 \pm 0.48$ \\
\hline & 40 & 150 & 60 & 100 & $100.26 \pm 0.45$ \\
\hline
\end{tabular}

*Mean of five determinations

\section{Precision}

The precision of the method was determined by repeatability (intraday precision) and intermediate precision (inter-day precision) of VAL standard solutions. Repeatability was calculated by assaying three samples of each three different concentration levels on the same day. The inter-day precision was calculated by assaying three samples of each at three different concentration levels on three different days. The results are expressed as a relative standard deviation. The relative standard deviations were below $2 \%$, which signifies the precision of both the methods (table 5).

Table 5: Precision of the method

\begin{tabular}{lll}
\hline Name of the formulation & Intra-day precision $(\mathbf{n}=\mathbf{6})$ & Inter-day precision $(\mathbf{n}=\mathbf{6})$ \\
\cline { 2 - 3 } & Mean*(\%) \pm RSD & Mean*(\%) \pm RSD \\
\hline Valzaar-80 & $99.97 \pm 0.35$ & $99.91 \pm 0.72$ \\
Diavon-80 & $100.11 \pm 0.33$ & $100.13 \pm 0.61$ \\
\hline
\end{tabular}

*Mean of three determinations injected six times at each concentration level

\section{Limits of detection (LOD) and quantification (LOQ)}

The LOQ and LOD were determined based on the 10 and 3.3 times the standard deviation of the response, respectively, divided by the slope of the calibration curve. The LOQ was found to be $0.26 \mu \mathrm{g} / \mathrm{ml}$, and the LOD was found to be $0.79 \mu \mathrm{g} / \mathrm{ml}$.

\section{Robustness}

In order to measure the extent of the method robustness, the most critical parameters were interchanged while keeping the other parameters unchanged, and in parallel, the chromatographic profile was observed and recorded. The chromatographic parameters were interchanged within the range of $1-10 \%$ of the optimum recommended conditions. The studied parameters were: mobile phase $\mathrm{pH}$, flow rate, and detector wavelengths. The results indicated that the small change in the conditions did not significantly affect the determination of VAL. Under all deliberately varied conditions, the \%RSD for the assay values $(n=3)$ for VAL was found to be well within the acceptance limit of $2 \%$. The results are reported in table 6 . 
Table 6: Results from testing the robustness of the method

\begin{tabular}{|c|c|c|c|c|}
\hline \multirow[t]{2}{*}{ Condition } & \multirow[t]{2}{*}{ Modification } & \multirow[t]{2}{*}{ Mean area* \pm SD } & \multirow{2}{*}{$\begin{array}{l}\text { RSD } \\
(\%)\end{array}$} & \multirow{2}{*}{$\begin{array}{l}\text { Mean } R_{T}^{*} \\
(\min ) \pm S D\end{array}$} \\
\hline & & & & \\
\hline Mobile phase flow & 0.8 & $7078494 \pm 16792$ & 0.23 & $29.95 \pm 0.05$ \\
\hline \multirow{2}{*}{ rate $(\mathrm{mL} / \mathrm{min})$} & 1 & $7062968 \pm 54957$ & 0.77 & $27.08 \pm 0.04$ \\
\hline & 1.2 & $7097530 \pm 57017$ & 0.8 & $26.95 \pm 0.15$ \\
\hline \multirow[t]{3}{*}{ Mobile Phase $\mathrm{pH}$} & 4 & $7033714 \pm 34615$ & 0.49 & $27.04 \pm 0.10$ \\
\hline & 4.2 & $7070556 \pm 17718$ & 0.25 & $27.08 \pm 0.04$ \\
\hline & 4.4 & $7074327 \pm 26629$ & 0.37 & $27.05 \pm 0.08$ \\
\hline \multirow[t]{3}{*}{ Detector wavelength (nm) } & 223 & $7072746 \pm 32695$ & 0.46 & $26.94 \pm 0.06$ \\
\hline & 225 & $7067339 \pm 20404$ & 0.28 & $26.94 \pm 0.11$ \\
\hline & 227 & $7077785 \pm 13108$ & 0.18 & $27.13 \pm 0.10$ \\
\hline
\end{tabular}

*Mean of three determinations

\section{Specificity and degradation studies}

When establishing the stability-indicating properties of analytical methods, the intermediate degradation products should not interfere with any stage of drug analysis. VAL was found to be stable at light and oxidation experiments. In acidic condition VAL degraded up to $9.2 \%$, in basic condition up to $6.5 \%$ and in thermal condition
$12.2 \%$ degradation was observed for VAL. The results from forced degradation studies are given table 7 .

Chromatograms obtained from after degradation under different stress conditions are shown in-fig. 4, respectively. No peaks coeluted with the drug peak, suggesting the method enabled specific analysis of VAL in the presence of its degradation products.

Table 7: Summary of forced degradation results of VAL

\begin{tabular}{|c|c|c|c|}
\hline Condition & Time & \% Assay of active substance & \% Degradation \\
\hline Treated with $5 \mathrm{ml}$ of $0.1 \mathrm{~N} \mathrm{HCl}$ solution and kept at $80^{\circ} \mathrm{C}$ on water bath & $2 \mathrm{~h}$ & 90.8 & 9.2 \\
\hline Treated with $5 \mathrm{ml}$ of $0.1 \mathrm{~N} \mathrm{NaOH}$ solution and kept at $80^{\circ} \mathrm{C}$ on water bath & $2 \mathrm{~h}$ & 93.5 & 6.5 \\
\hline $\begin{array}{l}\text { Treated with } 5 \mathrm{ml} \text { of } 10.0 \% \mathrm{H}_{2} \mathrm{O}_{2} \text { solution } \\
\text { and kept at } 80^{\circ} \mathrm{C} \text { on a water bath }\end{array}$ & $2 \mathrm{~h}$ & 98.2 & 1.8 \\
\hline Heated at $80^{\circ} \mathrm{C}$ in oven & $24 \mathrm{~h}$ & 87.8 & 12.2 \\
\hline Exposed in the UV chamber & $24 \mathrm{~h}$ & 98.8 & 1.2 \\
\hline
\end{tabular}
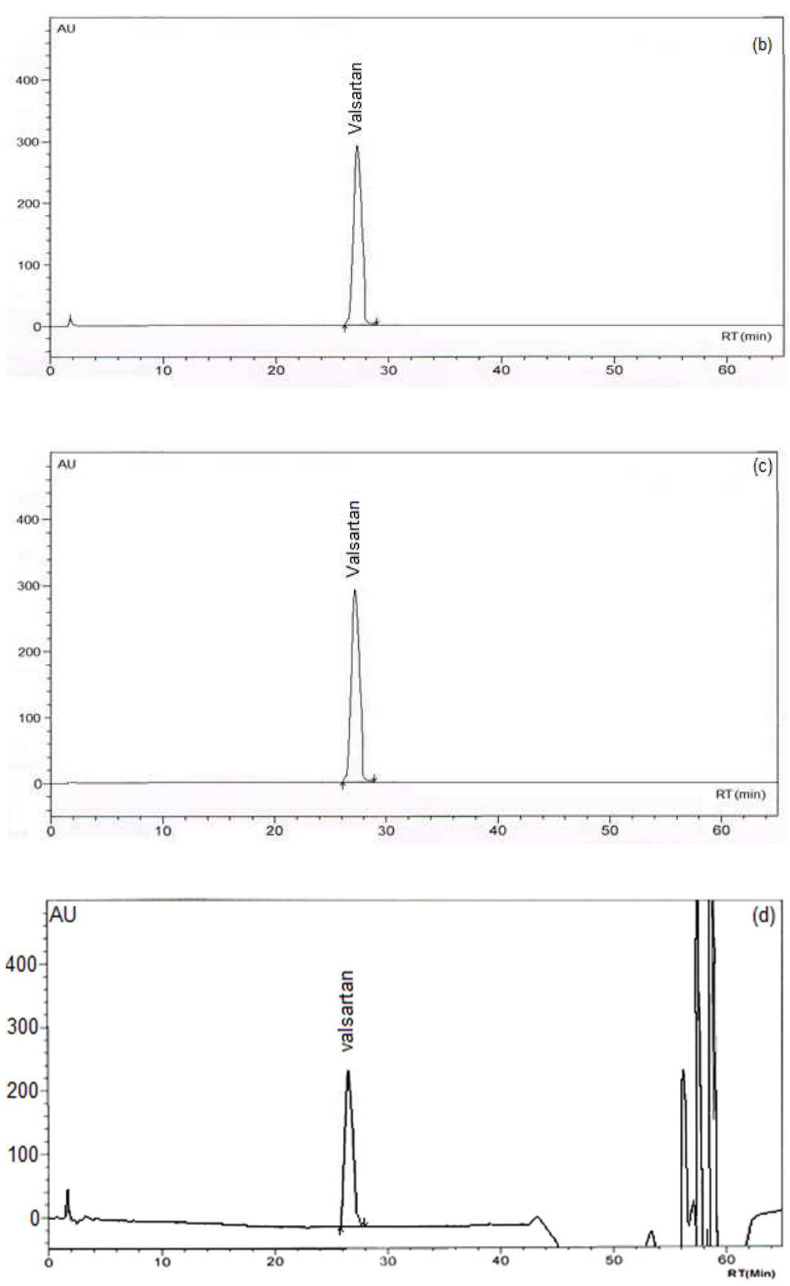
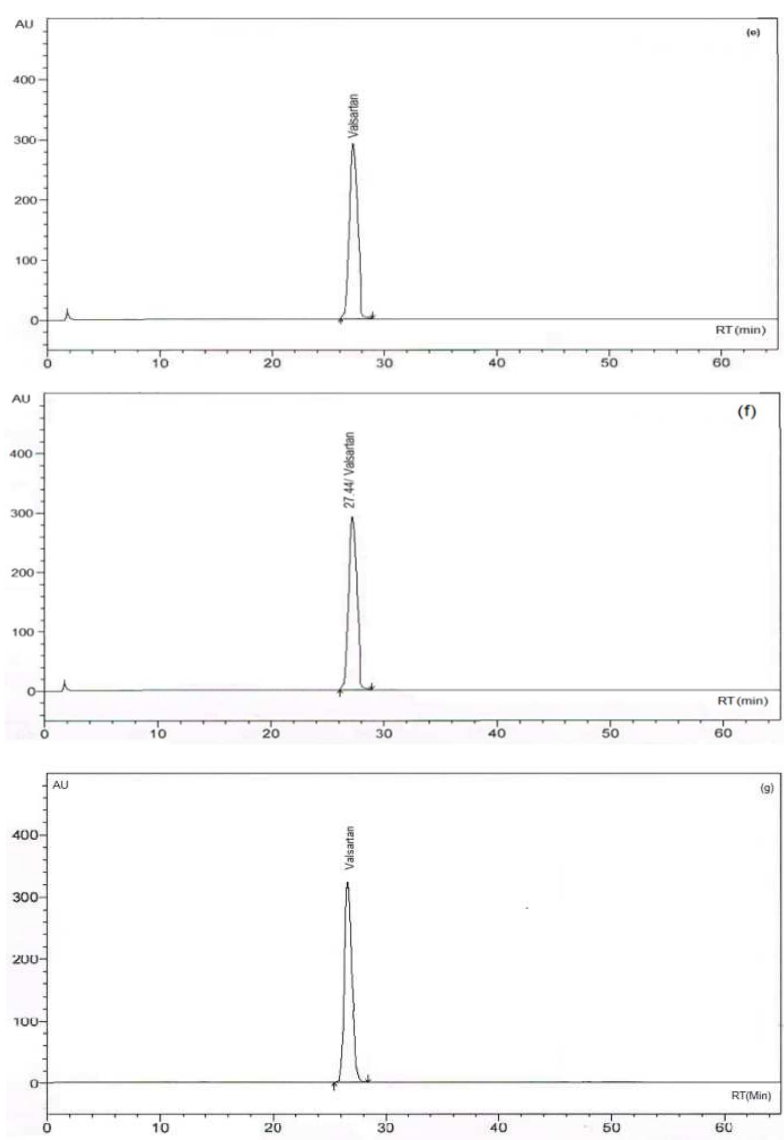

Fig. 4: LC chromatograms of Valsartan (a) after acidic degradation (b) after basic degradation (c) after oxidative degradation (d) after thermal degradation (e) after photodegradation (f) formulation I (g) Formulation II 


\section{Use of the method for analysis of marketed formulations}

Two marketed samples have been analyzed to see the performance of the method. The first formulation taken was Valzaar-80 which contains $80 \mathrm{mg}$ of VAL; the second formulation taken was Diavon-80 contains $80 \mathrm{mg}$ of VAL. Results obtained have been summarized in the table 8 .

Table 8: Results from assay of VAL in marketed formulation

\begin{tabular}{lcll}
\hline Formulation & Mean* $^{*}$ SD & RSD (\%) & Recovery (\%) \\
\hline Valzaar-80 & $80.04 \pm 0.33$ & 0.41 & 100.05 \\
Diavon-80 & $79.93 \pm 0.28$ & 0.35 & 99.91 \\
\hline
\end{tabular}

*Mean of six determinations

\section{Statistical comparison of gradient HPLC method and Isocratic HPLC}

To test the difference between the developed gradient liquid chromatographic method and our previous work isocratic HPLC method for estimation of VAL [16] statistical tests were performed for the level of confidence 95\% $(P=0.05)$. Two-way ANOVA and One-way ANOVA was applied to test both methods-sample interaction and differences in method precision. Two-way ANOVA was used for comparison of two formulations by two chromatographic methods (table 9). One way ANOVA was used for comparison of each formulation by chromatographic methods (table 9). To test means between different chromatographic methods paired student's $t$-test was applied. The test removes any variation between samples. For VAL, the two formulations were compared for the chromatographic methods (table 10).

Table 9: Comparison of chromatographic methods between valzaar-80 and diavon-80

\begin{tabular}{|c|c|c|c|c|c|c|}
\hline \multicolumn{7}{|c|}{ ANOVA-Two Way with replication } \\
\hline Source of Variation & SS & $d f$ & $M S$ & F stat & P-value & F crit \\
\hline Sample & 0.0082 & 1 & 0.0082 & 0.0868 & 0.7713 & 4.3512 \\
\hline Columns & 0.0031 & 1 & 0.0031 & 0.0331 & 0.8573 & 4.3512 \\
\hline Interaction & 0.0455 & 1 & 0.0455 & 0.4786 & 0.4969 & 4.3512 \\
\hline Within & 1.9010 & 20 & 0.0950 & & & \\
\hline \multicolumn{7}{|c|}{ Fstat $<$ Fcrit } \\
\hline \multicolumn{7}{|c|}{ ANOVA: Single Factor (VALZAAR-80) } \\
\hline Source of Variation & SS & $d f$ & MS & F stat & P-value & F crit \\
\hline Between Groups & 0.0363 & 1 & 0.0363 & 0.3221 & 0.5828 & 4.9646 \\
\hline Within Groups & 1.1269 & 10 & 0.1126 & & & \\
\hline \multicolumn{7}{|c|}{ Fstat $<$ Fcrit } \\
\hline \multicolumn{7}{|c|}{ ANOVA: Single Factor(DIAVON-80) } \\
\hline Source of Variation & SS & $d f$ & MS & F stat & P-value & F crit \\
\hline Between Groups & 0.0123 & 1 & 0.0123 & 0.1595 & 0.6979 & 4.9646 \\
\hline Within Groups & 0.7741 & 10 & 0.0774 & & & \\
\hline Fstat $<$ Fcrit & & & & & & \\
\hline
\end{tabular}

Table 10: Student's $t$-test for different chromatographic methods

\begin{tabular}{lll}
\hline t-Test: paired two sample for means & & \\
\hline Parameters & Valzaar-80 & Diavon-80 \\
Pearson correlation & -0.5097 & -0.4082 \\
t Stat & 0.5053 & 0.3460 \\
t Critical two-tail $=2.5705$ & $t$ stat<t crit & $t$ stat<t crit \\
\hline
\end{tabular}

\section{CONCLUSION}

A gradient stability-indicating reversed phase high performance liquid chromatographic method for valsartan in bulk and pharmaceutical dosage form was undertaken in the present research work. The method was found to be specific, as there was no interference of any co-eluting impurities after stress degradation study. The method was validated according to ICH guidelines and correlated by statistical analysis. The proposed method is found to be accurate, precise, sensitive and robust. Hence, it can be used successfully for the routine analysis of valsartan in pharmaceutical formulation and for analysis of stability samples obtained during accelerated stability study.

\section{ACKNOWLEDGMENT}

The authors express their sincere thanks to Macleod's Pharmaceuticals Ltd., India for providing gift sample of valsartan. Thanks are also due to the Professor and Chairman Siksha ' $O$ ' Anusandhan University, Bhubaneswar for providing laboratory facility for carrying out the present research work.

\section{CONFLICTS OF INTERESTS}

Declared none

\section{REFERENCES}

1. Budavari S. The Merck index, Merck and Co. Press. Edn 12. Whitehouse Station, New Jersey; 1997.
2. Kumari B, Garg R. Drug profile of valsartan: a review. World J Pharm Sci 2015;3:1598-606.

3. Kocyiğit KB, Unsalan S, Rollas S. Determination and validation of ketoprofen, pantoprazole and valsartan together in human plasma by high-performance liquid chromatography. Pharmazie 2006;61:586-9.

4. Daneshtalab N, Lewanczuk RZ, Jamali F. High performance liquid chromatographic analysis of angiotensin II receptor antagonist valsartan using a liquid extraction method. J Chromatogr B: Anal Technol Biomed Life Sci 2002;766:345-9.

5. González L, López JA, Alonso RM, Jiménez RM. Fast screening method for the determination of angiotensin II receptor antagonists in human plasma by high-performance liquid chromatography with fluorimetric detection. J Chromatogr A 2002;949:49-60.

6. Koseki N, Kawashita H, Haraa H, Niina M, Tanaka M, Kawai R, et al. Development and validation of a method for quantitative determination of valsartan in human plasma by liquid chromatography-tandem mass spectrometry. J Pharm Biomed Anal 2007;43:1769-74.

7. Hao L, Yingwu W, Yao J, Yunbiao T, Jiang W, Limei Z, et al. A liquid chromatography/tandem mass spectrometry method for the simultaneous quantification of valsartan and hydrochlorothiazide in human plasma. J Chromatogr B: Anal Technol Biomed Life Sci 2007;852:436-42.

8. Selvan PS, Gowda KV, Mandal U, Solomon WDS, Pal TK. Simultaneous determination of fixed dose combination of nebivolol and valsartan in human plasma by liquid 
chromatographic-tandem mass spectrometry and its application to pharmacokinetic study. J Chromatogr B: Anal Technol Biomed Life Sci 2007;858:143-50.

9. Jing $N$, Bingren X, Yuqi F, Danhua W. Isolation and identification of process impurities in crude valsartan by HPLC, mass spectrometry, and nuclear magnetic resonance spectroscopy. J Liq Chromatogr Relat Technol 2006;29:553-68.

10. Macek J, Klíma J, Ptácek P. Rapid determination of valsartan in human plasma by protein precipitation and high-performance liquid chromatography. J Chromatogr B: Anal Technol Biomed Life Sci 2006;832:169-72.

11. Hillaert S, Bossche VW. Simultaneous determination of hydrochlorothiazide and several angiotensin-II-receptor antagonists by capillary electrophoresis. J Pharm Biomed Anal 2003;31:329-39.

12. Satana E, Altmay S, Göger NG, Özkan SA, Sentürk Z. Simultaneous determination of valsartan and hydrochlorothiazide in tablets by first-derivative ultraviolet spectrophotometry and LC. J Pharm Biomed Anal 2001;25:1009-13.

13. Tatar S, Sağlík S. Comparison of UV-and second derivativespectrophotometric and LC methods for the determination of valsartan in a pharmaceutical formulation. J Pharm Biomed Anal 2002;30:371-5.

14. Agrahari V, Kabra V, Gupta S, Nema RK, Nagar M, Karthikeya C, et al. Determination of inherent stability of valsartan by stress degradation and its validation by HPLC. Int J Pharm Clin Res 2009;1:77-81.

15. Bhatia M Sudesh, Kokil S Uttamrao. Determination and validation of valsartan and its degradation products by isocratic HPLC. J Chem Metal 2009;3:1-12.

16. Sharma T, Moitra SK, Si SC, Sankar DG. Development and validation of a HPLC method for the determination of valsartan and its degradation products in a pharmaceutical formulation. Int J Pharm Pharm Sci 2012;4:299-303.

17. ICH. Stability Testing of New Drug Substances and Products. International Conference on Harmonization, IFPMA, Geneva; 2003.

\section{How to cite this article}

- $\quad$ Tripti Sharma, Sudan Chandra SI. A validated gradient stabilityindicating LC method for the analysis of valsartan in pharmaceutical dosage form. Int J Pharm Pharm Sci 2016;8(9):128-133. 